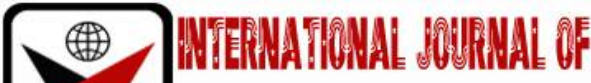

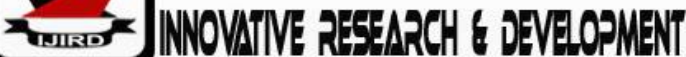

ISSN 2278-0211 (Online)

\section{To Examine the Competency of Internal Audit Staff in Rwanda Revenue Authority}

\author{
Kagaba Julius \\ Student School of Business \\ Jomo Kenyatta University of Agriculture and Technology, Kigali \\ Dr. Patrick Mulyungi \\ Lecturer, Schoolof Business and Economics, \\ Jomo Kenyatta University of Agriculture and Technology, Kenya
}

\begin{abstract}
:
The need for adequate internal audit staffing is essential for an institution to its operations, in Rwanda isincreasing significantly. Weakness in staffing can lead to mismanagement, error and abuse, which cannegate the effect of other controls. Skills development initiatives are top on the agenda of the internalaudit career. The purpose of this study was to examine the effect of competence of internal audit in thepublic organizations with Rwanda Revenue Authority as the case study. The Research adopted adescriptive research design Primary data was collected using questionnaires from a sample of 89employees of RRA comprising of 27 Managers/Supervisors and 62 Auditors. Data was analyzed fordescriptive statistics to provide details of demographic characteristics that affect the IA in the publicsector. While a correlation analysis was computed to evaluate the effects of various factors on internalauditors in the public sector. The results were presented in form of frequency tables and appropriatecharts. The result revealed that internal audit is significantly associated with educationqualification and experience as $((\chi 2=95.744, d f=6, p \& l t ; 0.001) \chi 2=142.306$, $d f=6, p \& l t ; 0.001$ and thusconfirmed that competence of internal audit is influenced by educational level of the internal auditor. It istherefore recommended that the IIA standardize and revise its guidance on required competencies andskills to enhance performance.
\end{abstract}

Keywords: Competency of internal audit staff, independence and objectivity of audit staff, work experience of internal audit staff, internal auditor

\section{Introduction}

The role of an internal auditing within the organization is not new to the business environment, the demand for internal auditing have changed significantly since the early twentieth century (Barac, Coetzee, Erasmus, Fourie, Motubatse, Plant, Steyn \& Van Staden 2010; PwC 2012). What has emerged from various studies is that the need now is for internal auditors who are able to assist management at strategicsystems and operational levels within the organization, in order to ensure sustainable businesses operations (PwC 2012).

The changes in the business environment together with cases of severe mismanagement and poor governance, have contributed significantly to an increased need for competent internal audit activity that provides one of the cornerstones of effective corporate governance (Harrington 2014; Stačiokas\&Rupšys 2015; IOD 2010). The emphasis on internal auditing in governance guidance codes and in legislation globally, has also increased substantially in recent years (Coetzee 2010). In addition, internal auditors are increasingly required to provide assurance on the effectiveness of governance processes (IIA 2011), and to move from the backroom to the boardroom (Von Eck 2009), providing advice to management on matters such as enterprise risk management, the control environment, and sustainability (PwC 2011).

The profession is growing at a tremendous rate: internationally membership increased by $137.5 \%$ from 2000 to 2010 (L.S. Stanley, Membership consultant at the IIA Inc)). However, there is still a shortage of competent internal auditors in Rwanda, as indicated by the Government chief internal manual which recognizes internal auditing as a scarce skill (Internal audit manual 2011). Another study performed by PricewaterhouseCoopers in South Africa (PwC 2011) identified internal auditing as a highly sought-after, scarce skill. 


\section{Literature Review}

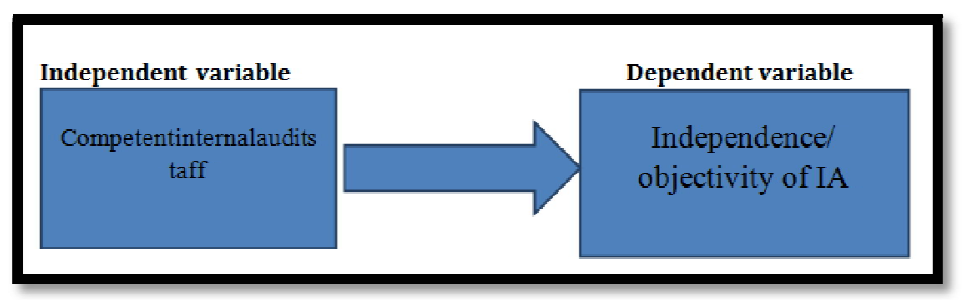

Figure 1: Conceptual Frameworks

According to Mautz et al (2010), internal auditing was a well-established and well-respected activity, but by the nineteen-eighties there was little indication that it was well-defined or clearly directed. Since the above statement was made by Mautz several developments have occurred that define and direct the internal audit profession. This has since been regularly updated, and currently the IPPF (IIA 2011) consists of six elements providing guidelines on the role and responsibilities of the internal audit function.The IPPF includes guidance on competencies identified as necessary for internal auditors to have mastered for them to do their work effectively. The IPPF consists of the definition of internal auditing, a code of ethics, International Standards for the Professional Practice of Internal Auditing (hereafter refer to as Standards), and various practice advisories. The definition, code of ethics and the Standards, and the mandatory guidance component of the IPPF, together provide guidance on proficiency and skills requirements for internal auditors (IIA 2011). Specific skills and competency required, taken from mandatory guidance documents, include, inter alia: adding value; risk management, analysis and interpretation; integrity, objectivity, and confidentiality (IIA 2011), which form the basis of the IACF.

For purposes of this research, the term 'internal audit staff' refers to new internal auditors and to internal auditors who are not at supervisory, management or chief audit manager levels. It can be assumed that some of these individuals are still in the process of gaining the required practical experience (as stipulated by the IIA), as part of the certification program. Globally, limited research has been conducted on the competency requirements specifically for entry-level internal auditors (Seol, Sarkis \&Lefley 2011). In South Africa, Barac (2010) has studied the knowledge and skills required for entry-level accounting trainees, as perceived by training officers, whereas Plant and Steyn (2015) examined the education considerations for internal auditors. No literature could be found on the specific requirements for internal audit staff, except for the IACF issued by the IIA 2012.Common levels of competencies for internal staff include, General competencies involving communication skills, Problem identification and solution skills, Industry regulatory and standards changes, Staff training and development, Behavioral skills competencies that consist of Change catalyst, Staff management, Team building/creating group synergy, Work independently and Leadership whereas Technical skills competencies includes, Forecasting, ISO/quality knowledge, Financial analysis tools and techniques and Forensic skills/fraud awareness etc.

\section{Methodology}

Descriptive research design was adopted and data collected from 89 employees (27 Managers/Supervisors and 62 Auditors) of Rwanda Revenue Authority comprising of using a closed ended questionnaires.Data was analyzed for descriptive statistics to provide details of demographiccharacteristics thataffecttheIAinthepublicsector. While a correlation analysiswas computed toevaluatetheeffectsofvariousfactors oninternalauditorsinthepublicsector. The results were presented in form of frequency tables and appropriate charts

\section{Results and Findings}

\subsection{Descriptive Analysis of Variables of the Study}

- The Table 1 Below explain the general findings regarding the respondents age, sex and education level for all respondents. 53 (59.6\%) were males and 36 (40.4\%) were females. As shown by the respondents many respondents were male than female.

- $\quad$ This part, (B), show the age of respondents, most respondents have age between $40-49$ (43.8\%), followed by those who have age ranging between 30 - 39 (34.8\%) while those who have age between 20-29 and 5 and above equal to $7.9 \%$ and $13.5 \%$. This data indicates that the majority of RRA staff is not too old.

- In terms of the level of educational background, most managers and internal auditors have bachelor's degree $55(61.8 \%)$ followed by those who have Master's degree $29(32.6 \%)$ and Phd holder are 5person constituted by(5.6\%) and those who have other qualification like, CPA constituted by $23.6 \%$.

- $\quad$ Regarding work experience 1-5 (44.9\%), 6-9 (33.7\%) whereas above 10 years of work are at (23.3\%) this implies that the work experience of RRA IA staff is in the range of 1-5 years followed by 6-10 years and above 10 years the number reduced $21.3 \%$.

- Continuous professional development based on the above findings RRA still have few IA staff with certification in auditing and accounting many of them under go for soft courses which is represented by $86.5 \%$.

- The university degree of an entry level of internal auditor represented by $55(61.8 \%)$ is clear reflection that Educational qualification is significantly associated with independence/objectivity of internal audit competence $(\chi 2=95.744, \mathrm{df}=6, \mathrm{p} \& \mathrm{lt} ; 0.001)$. whereas work experience of internal auditor as indicated by 40 (44.9\%) is 
significantly influenced by independence/objectivity at $95 \%(\chi 2=142.306, \mathrm{df}=6, \mathrm{p} \& \mathrm{lt} ; 0.001)$. while continuous professional development is insignificantly associated as shown by P-value $(\chi 2=18.615, \mathrm{df}=12, \mathrm{p}=0.098)$.

\begin{tabular}{|c|c|c|c|}
\hline Variable & Category & Frequency & Percentage \\
\hline \multirow{3}{*}{ A. $\quad$ Gender } & Female & 36 & $40.4 \%$ \\
\hline & Male & 53 & $59.6 \%$ \\
\hline & Total & 89 & $100.0 \%$ \\
\hline \multirow[t]{7}{*}{ B. $\quad$ Age } & $20-29$ & 7 & $7.9 \%$ \\
\hline & $30-39$ & 28 & $31.5 \%$ \\
\hline & $30-39$ & 3 & $3.4 \%$ \\
\hline & $40-49$ & 32 & $36.0 \%$ \\
\hline & $40-49$ & 2 & $2.2 \%$ \\
\hline & 50 and above & 17 & $19.1 \%$ \\
\hline & Total & 89 & $100.0 \%$ \\
\hline \multirow[t]{4}{*}{ C. $\quad$ Educational level } & Degree & 55 & $61.8 \%$ \\
\hline & Masters & 29 & $32.6 \%$ \\
\hline & PhD & 5 & $5.6 \%$ \\
\hline & Total & 89 & $100.0 \%$ \\
\hline \multirow[t]{4}{*}{ D. Work experience, } & $1-5$ & 40 & $44.9 \%$ \\
\hline & $6-10$ & 30 & $33.7 \%$ \\
\hline & Above 10 & 19 & $21.3 \%$ \\
\hline & Total & 89 & $100.0 \%$ \\
\hline \multirow{6}{*}{$\begin{array}{l}\text { E. Continuous } \quad \text { professional } \\
\text { development }\end{array}$} & A.T & 2 & $2.2 \%$ \\
\hline & ACCA & 2 & $2.2 \%$ \\
\hline & CIA & 3 & $3.4 \%$ \\
\hline & $\mathrm{CPA}$ & 5 & $5.6 \%$ \\
\hline & Other & 77 & $86.5 \%$ \\
\hline & Total & 89 & $100.0 \%$ \\
\hline
\end{tabular}

Table 1: Descriptive Analysis of Variables of the Study

\subsection{Bivariate Analysis of Competence of Internal Audit Staff and Independence}

The Table 2 shows the effect of competent internal audit staff on internal audit function in RRA with regards to the level of education,experience, independence and objectivity. The findings show that education and experience significantly contribute to independence and objectivity whereas continuous profession development is insignificantly associated with independence reflected in table below 55 (61.8\%), 40 (44.9\%) and 2 (2.2\%) The role of internal audit in an organization is to evaluate the internal controls which brings about safeguarding of assets and improved performance. The importance of competent internal auditors assist management at strategic systems and operational levels within the organization, in order to ensure sustainable businesses operations (PwC 2012). RRA need adequate skilled internal auditorsapplicable to the professionthe specific skills and competencies required include adding value, risk management, analysis and interpretation, integrity, objectivity, and confidentiality (IIA 2011) which form the basis for IACF.

\begin{tabular}{|c|c|c|c|c|c|c|c|c|c|c|c|}
\hline & & \multicolumn{10}{|c|}{ Independence/objectivity of IA } \\
\hline & & \multicolumn{2}{|c|}{ Disagree } & \multicolumn{2}{|c|}{ Undecided } & \multicolumn{2}{|c|}{ Agree } & \multicolumn{2}{|c|}{ Strongly Agree } & \multicolumn{2}{|c|}{ Total } \\
\hline & & $\mathbf{n}$ & $\%$ & $\mathbf{N}$ & $\%$ & $\mathbf{n}$ & $\%$ & $\mathbf{n}$ & $\%$ & $\mathbf{N}$ & $\%$ \\
\hline \multirow{5}{*}{$\begin{array}{c}\text { Educational } \\
\text { level }\end{array}$} & Degree & 0 & $0.0 \%$ & 0 & $0.0 \%$ & 17 & $19.1 \%$ & 38 & $42.7 \%$ & 55 & $61.8 \%$ \\
\hline & Masters & 9 & $10.1 \%$ & 16 & $18.0 \%$ & 4 & $4.5 \%$ & 0 & $0.0 \%$ & 29 & $32.6 \%$ \\
\hline & $\mathrm{PhD}$ & 5 & $5.6 \%$ & 0 & $0.0 \%$ & 0 & $0.0 \%$ & 0 & $0.0 \%$ & 5 & $5.6 \%$ \\
\hline & Total & 14 & $15.7 \%$ & 16 & $18.0 \%$ & 21 & $23.6 \%$ & 38 & $42.7 \%$ & 89 & $100.0 \%$ \\
\hline & \multicolumn{8}{|c|}{$\chi 2=95.744, \mathrm{df}=6, \mathrm{p}<0.001$} & & & \\
\hline \multirow{5}{*}{$\begin{array}{c}\text { Work } \\
\text { experience, }\end{array}$} & $1-5$ & 0 & \begin{tabular}{l|l}
$0.0 \%$ \\
\end{tabular} & 0 & \begin{tabular}{l|l}
$0.0 \%$ & \\
\end{tabular} & 2 & $2.2 \%$ & 38 & $42.7 \%$ & 40 & $44.9 \%$ \\
\hline & $6-10$ & 0 & $0.0 \%$ & 11 & $12.4 \%$ & 19 & $21.3 \%$ & 0 & $0.0 \%$ & 30 & $33.7 \%$ \\
\hline & Above 10 & 14 & $15.7 \%$ & 5 & $5.6 \%$ & 0 & $0.0 \%$ & 0 & $0.0 \%$ & 19 & $21.3 \%$ \\
\hline & Total & 14 & $15.7 \%$ & 16 & $18.0 \%$ & 21 & $23.6 \%$ & 38 & $42.7 \%$ & 89 & $100.0 \%$ \\
\hline & \multicolumn{7}{|c|}{$\chi 2=142.306, \mathrm{df}=6, \mathrm{p}<0.001$} & & & & \\
\hline \multirow{7}{*}{$\begin{array}{l}\text { Continuous } \\
\text { professional } \\
\text { development }\end{array}$} & A.T & 0 & $0.0 \%$ & 0 & $0.0 \%$ & 0 & $0.0 \%$ & 2 & $2.2 \%$ & 2 & $2.2 \%$ \\
\hline & ACCA & 0 & $0.0 \%$ & 0 & $0.0 \%$ & 0 & $0.0 \%$ & 2 & $2.2 \%$ & 2 & $2.2 \%$ \\
\hline & CIA & 0 & $0.0 \%$ & 0 & $0.0 \%$ & 0 & $0.0 \%$ & 3 & $3.4 \%$ & 3 & $3.4 \%$ \\
\hline & CPA & 0 & $0.0 \%$ & 0 & $0.0 \%$ & 0 & $0.0 \%$ & 5 & $5.6 \%$ & 5 & $5.6 \%$ \\
\hline & Other & 14 & $15.7 \%$ & 16 & $18.0 \%$ & 21 & $23.6 \%$ & 26 & $29.2 \%$ & 77 & $86.5 \%$ \\
\hline & Total & 14 & $15.7 \%$ & 16 & $18.0 \%$ & 21 & $23.6 \%$ & 38 & $42.7 \%$ & 89 & $100.0 \%$ \\
\hline & \multicolumn{7}{|c|}{$\chi 2=18.615, d f=12, p=0.098$} & & & & \\
\hline
\end{tabular}

Table 2: Bivariate Analysis of Competence of Internal Audit Staff and Independence

P-Value Is Significant At 0.05 


\subsection{Correlation between Competence of Internal Audit Staff and Independence/Objectivity of IA}

The table 3. below reflects the correlation between competence of internal audit staff and independence: The result of both Education level and work experience which has 0.869 and 0.800 are significantly associated with the internal audit competence at the $\mathrm{p}<0.01,{ }^{*} \mathrm{p}<0.05$, whereas the correlation between Competence of internal audit and Continuous professional development is insignificantly associated with independence at 0.329 Ap-value of less than 0.05 , which is projected as the Sig. value of 0.00 .

\begin{tabular}{|c|c|c|c|c|}
\hline & $\begin{array}{c}\text { Independence/Objectivity } \\
\text { of IA }\end{array}$ & $\begin{array}{c}\text { Educational } \\
\text { Level }\end{array}$ & $\begin{array}{c}\text { Continuous } \\
\text { Work } \\
\text { Experience }\end{array}$ & $\begin{array}{c}\text { prossional } \\
\text { development }\end{array}$ \\
\hline $\begin{array}{c}\text { Independence/objectivity } \\
\text { of IA }\end{array}$ & 1 & $-.869^{* *}$ & $-.941^{* *}$ & $-.329^{* *}$ \\
\hline Educational level & $-.869^{* *}$ & 1 & $.800^{* *}$ & $.250^{*}$ \\
\hline Work experience, & $-.941^{* *}$ & $.800^{* *}$ & 1 & $.335^{* *}$ \\
\hline $\begin{array}{c}\text { Continuous professional } \\
\text { development }\end{array}$ & $-.329^{* *}$ & $.250^{*}$ & $.335^{* *}$ & 1 \\
\hline
\end{tabular}

Table 3: Correlation between Competence of Internal Audit Staff and Independence ${ }^{* *} P<0.01,{ }^{*} P<0.05$

Source: Field Research Data, 2019

\subsection{Multi Regression Analysis}

According to the results in the table 4 below, the value of $\mathrm{R}^{2}$ is 0.961 . This indicates that there was a variation of $96 \%$ of internal audit in RRA at a confidence level of 95\% which is strong and positive. This means that approximately $96 \%$ variations of internal auditing are explained by the four sub variables, at $5 \%$ level of significance. These indicate good fit of the regression equation used.

\begin{tabular}{|c|c|c|c|c|}
\hline \multicolumn{4}{|c|}{ Multi Regression Analysis } \\
\hline Model & $\mathrm{R}$ & R Square & $\begin{array}{c}\text { Adjusted R } \\
\text { Square }\end{array}$ & Std. Error of the Estimate \\
\hline 1 & $.961^{\mathrm{a}}$ & .923 & .921 & .314 \\
\hline
\end{tabular}

Table 4 Model Summary

a. Predictors: (Constant), Continuous Professional, Development, Educational Leveland Work Experience, b. Dependent Variable: Internal Audit Independence

\section{5. $A N O V A^{a}$}

Table 5 shows the overall significance of the regression estimation model indicates that the model is significant in explaining the relationship between internal audit competence and independence/objectivity at 5\% level of significance. This implies that the regression equation was well specified and therefore the co-efficient of the regression shows that there is a strong relationship between internal audit competence and independence. The analysis of variance of the predictors of the model has a significance of 0.000 .

\begin{tabular}{|c|c|c|c|c|c|c|}
\hline \multicolumn{2}{|c|}{ Model } & $\begin{array}{c}\text { Sum of } \\
\text { Squares }\end{array}$ & df & $\begin{array}{c}\text { Mean } \\
\text { Square }\end{array}$ & F & Sig. \\
\hline \multirow{2}{*}{1} & Regression & 101.191 & 3 & 33.730 & 341.149 & $.000^{\mathrm{b}}$ \\
\cline { 2 - 7 } & Residual & 8.404 & 85 & .099 & & \\
\cline { 2 - 7 } & Total & 109.596 & 88 & & & \\
\hline
\end{tabular}

Table 5: ANOVAa

a. Dependent Variable: Independence/objectivity of IA

b. Predictors: (Constant), Continuous professional development, Educational level, Work experience,

\section{Discussion of Findings}

The study found that Educational qualification and work experience significantly influence independence/objectivity of internal audit competence in Rwanda Revenue authority. The Person correlation coefficient of 0.867 and 0.80 indicate that both Education level and work experience are strongly associated with internal audit competence at the $\mathrm{p}<0.01,{ }^{*} \mathrm{p}<0.05$, whereas the correlation between Competence of internal audit and Continuous professional development is negatively associated with independence at 0.329 Ap-value of less than 0.05, which is projected as the Sig. value of 0.00. The multiple regression findings show that the value of $\mathrm{R}^{2}$ is 0.961 . This indicates that there was a variation of $96 \%$ of internal audit in RRA at a confidence level of $95 \%$ which is strong and positive.This means that approximately $96 \%$ variations of internal auditing are explained by the four sub variables, at $5 \%$ level of significance. These reflect good fit of the regression equation used. The findings of this study are consistent with previous studies that project the importance of internal audit independence in improving internal audit effectiveness such as Stewart, 
J. and Subramaniam, N. (2010) where they stressed that internal auditor independence helps to enhance the work of the internal auditors. The findings from this research were supported by the earlier studies such as ZulkifliBaharuddin (2014); Sayag (2010); George et al. (2015); Alzeban\&Gwilliam (2014); Angus OkechukwaUnegbu and Mohamad Isa Kida (2011) as far as the Competency of internal auditors is concerned.

These researchers found that internal auditors can effectively carry out their duties if they possess the required competencies. According to the IIA (2013), auditors are required to possess the knowledge, skills and competencies required to practice their profession. Academic qualifications, effective communication skillset and enough work experience are some of the other qualities needed for optimal performance.The importance of competent internal auditors assist management at strategic systems and operational levels within the organization, in order to ensure sustainable businesses operations (PwC 2012). RRA need adequate skilled internal auditors applicable to the profession the specific skills and competencies required include adding value, risk management, analysis and interpretation, integrity, objectivity, and confidentiality (IIA 2011) which form the basis for IACF.

Based on the findings, there is a significant relationship between internal auditor competence and internal audit independence and objectivity. These findings are consistent with a study done by Ali, et al. (2013) where he says that the internal auditor's incompetence is an obvious factor of internal audit effectiveness in the internal audit functions in state owned institutions of Rwanda. However the findings of this study contradict with the findings of Mihret, James and Mula (2010, p. 240) They asserted that technical competence and continuous training are considered essential for effective internal audit.

\section{Conclusion}

The purpose of this article is to examine the competency of internal audit staff in the public institution Rwanda Revenue Authority being my point of reference. The competentinternalaudit staff to the development of public organizations. The Staff result showed that those sub-variables have significant and positive effect on the internal audit. The ability of independent variables to explain the dependent variable is $80.5 \%$. Inevitably, this study has methodological limitations. It is questionnaire-based, and a measure of the variables, both the dependent and independent variable, is established according to the perceptions of the internal auditors. Besides this research used small number of populations, so the result will be difficult to be generalized to measure factors affecting the internal audit effectiveness.

\section{Recommendation of the Study}

Internal audit needs to adopt a new approach in view of the many changes that are taking place in the public corporation's environment. In the occurrence of financial humiliations, strong emphasis on corporate governance, active oversight and comprehensive internal controls would assist an organization.

The audit structure must be improved, and the internal audit executive should report to the Board of Directors. Internal audit should get support from management, Audit should be independent and given correct auditing tools. Top management should accept audit findings and correct errors rather than view audit as fault finders. Audit staff should have required qualification and should be adequately remunerated. Management should demonstrate commitment to implement audit findings. Management should respond to all findings and recommendations on time.

Management should cooperate with auditors. Management should give support and allocate adequate resources to internal audit training. Management should accept auditors as improvers of the system rather than witch hunters. Auditors should embark on continuous professional development/training. Auditors should always be objective and factual. Auditors should be friendly and approachable and constantly strive to improve their performance. Auditors need to have knowledge of the area being audited.

\section{References}

i. Alzeban, A. \&Gwilliam, D. (2014). Factors affecting the internal audit effectiveness: A survey of the Saudi public sector. Journal of International Accounting, Auditing and Taxation, 23(2), pp. 74-86.

ii. Arena, M. \&Azzone, G. (2010), "Identifying Organizational Drivers of Internal Audit Effectiveness, International Journal of Auditing

iii. Cohen, A. \&Sayag, G. (2010). The effectiveness of internal auditing: an empirical examination of its determinants inIsraeli organizations. Australian Accounting Review, 20(3), pp. 296-307

iv. Coetzee, GP (2010), A risk-based audit model internal audit engagement unpublished PHD (Auditing) thesis University of the Free State, Bloemfontein.

v. Bailey J.A (2010). Core competencies for today's Internal Auditor, the Institute of Internal Auditors Research Foundation Altamonte Springs, Florida.

vi. Global Accounting Alliance. (2012), Alliance bodies of the global auditing Alliance

vii. Institute of Directors (2010) King report on governance for South Africa. King committee on corporate governance Johannnesburg.

viii. Institute of Internal Auditors (IIA). “Global Internal Audit Competency Framework” (2013) Altamonte Springs, FL: IIA. IIA, the 2011 International professional practice framework. IIA Altamonte Spring Florida.

ix. Motubatse Plant Steyn et el (2010), the standing of and demand for Internal Auditor in South Africa Listed Companies.

x. Price Water House Coopers (PWC) 2012 state of the Internal Audit Profession

xi. Seol I, Sarkas\&Lefley (2011) Factor structure of the competency framework for internal auditing (CFIA) skills forentering levelIA. 
xii. Stewart,J. and Subramaniam,N ․ (2010), "Internal audit independence

and

objectivity:

emerging researchopportunities", ManagerialAuditingJournal, Vol. 25 No. 4, pp. 328-360.

xiii. Van Peursem, K. (2010), "Conversations withInternalAuditors: The Power of Ambiguity" ManagerialAuditingJournal. 